\title{
Anxiolytic and Explorative Potentials of the Methanol Leaf Extract of Vernonia Amygdalina in Male Wistar Rats
}

Lawrence Dayo ADEDAYO ${ }^{*}$,Gbenro Seun AKINTOLA', Alaba Olumide OJ O', Olubayode BAMIDELE ${ }^{1}$, Nimedia Gideon AITOKHUEHI ${ }^{2}$ and Abiodun Oladele AYOKA ${ }^{3}$

${ }^{1}$ Neurophysiology Unit, Department of Physiology, Faculty of Basic Medical and Health Sciences, Bowen University, Nigeria

${ }^{2}$ Neurosciences and Oral Physiology Unit, Department of Physiology, University of Ibadan, Nigeria

${ }^{3}$ Department of Physiological Sciences, Faculty of Basic Medical Sciences, Obafemi Awolowo University, Nigeria *Corresponding author: Lawrence Dayo ADEDAYO, Neurophysiology Unit, Department of Physiology, Faculty of Basic Medical and Health Sciences, Bowen University, Iwo, Nigeria

Received: May 24, 2018; Accepted: J une 22, 2018; Published: J une 29, 2018

\begin{abstract}
Anxiety is an unpleasant state of inner turmoil which causes nervous behavior like fear, apprehension and worries. Vernonia amygdalina commonly called bitter leaf, belongs to the family Astaraceae, and has been reported to be used locally in the management of psychiatric disorders. However, no work has been reported on pharmacological potentials of Vernonia amygdalina on anxiety in male rats. This study was therefore designed to investigate the effect of Vernonia amygdalina (VA) on anxiety status in male rats.
\end{abstract}

The air-dried leaves of Vernonia amygdalina (VA) pulverized and macerated in methanol for 72 hours. The methanol was filtered with cotton wool and filter paper and concentrated using rotary evaporator at $40^{\circ} \mathrm{C}$ and further concentrated in a vacuum oven at temperature of $40^{\circ} \mathrm{C}$ and pressure of $600 \mathrm{mmHg}$. The anxiolytic-like effect of VA was investigated using the Open Field Test (OPF), Hole-board apparatus and Y-maze apparatus. The results obtained were expressed as mean \pm S.E.M. Data were analyzed using Oneway Analysis of Variance (ANOVA), followed by Newman- Keuls' multiple comparisons test $P<0.05$.

Vernonia amygdalina showed anxiolytic-like effect in rat, $50 \mathrm{mg} / \mathrm{kg}$ were significantly different from control in open field test, hole board test.

In conclusion, this study has shown that methanol extract Vernonia amygdalina possess anxiolytic-like effects in male rats.

Keywords: Vernonia amygdalina; Anxiety; Hole-Board Apparatus; Open field test

\section{Introduction}

Anxiety is a state of excessive fear and is characterized by motor sympathetic hyperactivity, apprehension and vigilance syndromes. It can lead to feelings of dread over something unlikely to happen, such as feeling of imminent death and it is often accompanied by muscular tension, restlessness, fatigue and problems with concentration. Generalized anxiety disorder is an ongoing state of excessive anxiety lacking any clear reason or focus. Essential feature of this class of anxiety is chronic worry [1].

Anxiety is a normal human emotion that is experienced at times, closely allied with fear and presumably serving psychobiologically adaptive purposes. While anxiety is considered a natural reaction to a stressful situation, however when symptoms of anxiety occur frequently, extending over a period of time and interfering with daily activities, it is typically considered an anxiety disorder. Anxiety disorders include panic, social anxiety, specific phobias and generalized anxiety.

All anxiolytic agents like benzodiazepines (BDZs) bind to the gamma sub-unit of the GABA-A receptor. Their binding causes an allosteric (structural) modification of the receptor that result in an increase in $\mathrm{GABA}_{\mathrm{A}}$ receptor activity. BDZs do not substitute for GABA, which bind at the alpha sub-unit, but increase the frequency of channel opening events which leads to an increase in chloride ion conductance and inhibition of the action potential. Benzodiazepines work by increasing the efficiency of a natural brain chemical, GABA, to decrease the excitability of neurons. This reduces the communication between neurons and therefore, has a calming effect on many of the functions of the brain. GABA controls the excitability of neurons by binding to the $\mathrm{GABA}_{\mathrm{A}}$ receptor [2]. The $\mathrm{GABA}_{\mathrm{A}}$ receptor is a protein complex located in the synapses of neurons. All GABA $A_{A}$ receptors contain an ion channel that conducts chloride ions across neuronal cell membranes and two binding sites for the neurotransmitter gamma-aminobutyric acid (GABA), while a subset of $\mathrm{GABA}_{\mathrm{A}}$ receptor complexes also contain a single binding site for benzodiazepines. Binding of benzodiazepines to this receptor complex does not alter binding of GABA.

Unlike other positive allosteric modulator that increases ligand binding, benzodiazepine binding acts as a positive allosteric modulator by increasing the total conduction of chloride ions across the neuronal cell membrane when GABA is already bound to its receptor. This increased chloride ion influx hyperpolarizes the neuron's membrane potential. As a result, the difference between resting potential and threshold potential is increased and firing
Ann Depress Anxiety - Volume 5 Issue 1 - 2018

ISSN : 2381-8883 | www.austinpublishing group.com

Lawrence et al. ( ) All rights are reserved
Citation: Lawrence DA, Gbenro SA, Alaba OO, OLubayode B, Nimedia GA and Abiodun OA. Anxiolytic and Explorative Potentials of the Methanol Leaf Extract of Vernonia Amygdalina in Male Wistar Rats. Ann Depress Anxiety. 2018; 5(1): 1094. 




Figure 1: Effect of MEVA administration on number of line crossed in Open Field Test (OFT). The results were expressed as means $\pm \operatorname{SEM}(n=6)$. Data were analyzed using One-way ANOVA followed by Newman-Keuls' post hoc test. ${ }^{* \star *} p<0.001$ compared with the control.

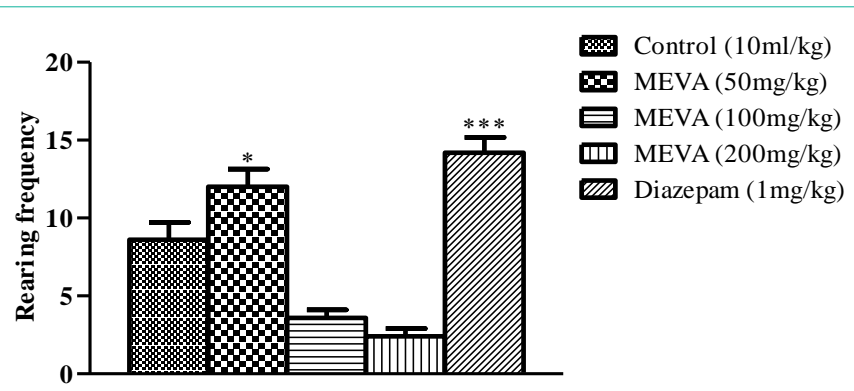

Figure 2: Effect of MEVA administration on Rearing in Open Field Test (OFT) The results are expressed as means \pm SEM $(n=6)$. Data were analyzed using One-way ANOVA followed by Newman-Keuls' post hoc test. * $p<0.05$, ${ }^{* \star \star} p<0.001$ compared with the control.

is less likely. Different $\mathrm{GABA}_{\mathrm{A}}$ receptor subtypes have varying distributions within different regions of the brain and, therefore, control distinct neuronal circuits. Hence, activation of different $\mathrm{GABA}_{\mathrm{A}}$ receptor subtypes by benzodiazepines may result in distinct pharmacological actions [3]. In terms of the mechanism of action of benzodiazepines, their similarities are too great to separate them into individual categories such as anxiolytic or hypnotic. For example, a hypnotic administered in low doses will produce anxiety-relieving effects, whereas a benzodiazepine marketed as an anti-anxiety drug will at higher doses induce sleep [4]. Despite immense technological advancement in modern medicine, many people in developing countries still rely on the healing properties of medicinal plants for their health care needs.

Vernonia amygdalina (VA), a member of the Asteraceae family, is a small shrub that grows in the tropical Africa. V. amygdalina typically grows to a height of $2-5 \mathrm{~m}$. The leaves are elliptical and up to $20 \mathrm{~cm}$ long. Its bark is rough [5]. V. amygdalina is commonly called bitter leaf in English because of its bitter taste. Locally, VA is called ewuro (Yoruba), onugbu (Igbo), chusar-doki (Hausa) [6,7].

Vernonia amygdalina (Del.) commonly called bitter leaf is the most widely cultivated species of the genus Vernonia which has about 1,000 species of shrubs [8]. It belongs to the family Astaraceae. It is vegetative cultivated by stem cutting at an angle of $45^{\circ} \mathrm{C}$ and popular in most of West Africa countries including Nigeria, Cameroon, Gabon and Congo Democratic Republic. It was named after an English Botanist William Vernon. It is also referred to as ironweed.



Figure 3: Effect of MEVA administration on Grooming in Open Field Test (OFT). The results are expressed as means \pm SEM $(n=6)$. Data were analyzed using One-way ANOVA followed by Newman-Keuls' post hoc test. ${ }^{*} p<0.05$ compared with the control.

V. amygdaline is frequently found in gardens [9]. It can adapt to a variety of climates unlike other plants that are native to certain areas. It is grown in many countries, in savannah zones and cultivated fields.

Although most popularly used for food, it has also, been traditionally used for its medicinal properties [10]. True to its name, bitter leaf is bitter to taste but surprisingly delicious in meals [11]. Bitter leaf is called Omjunso in East Africa especially Tanzania, Onugbo in Igbo-Eastern Nigeria and Orugbo among the Itsekiri and Urhobo tribes in Nigeria, Ewuro (Yoruba), Etidot (Ibibio), Ityuna (Tiv), Oriwo (Edo), Chusa-doki Shiwaka (Hausa).

It attains the height of $2.5 \mathrm{~m}$ with petiolate leaf of about $6 \mathrm{~mm}$ in diameter that is elliptic in shape [5]. The branches are brittle and break off easily. It has grey or brown coloured bark; the bark has a rough texture and is flaked. The leaves are elliptical and up to $20 \mathrm{~cm}$ long.

Studies have shown that there is evidence that Vernonia amygdalina possess anti-hypertensive activity [12,13], antidiabetic activity [14,15], antiplatelet potential [16], hypolipidaemia activity $[17,18]$ and hepatoprotective activity $[19,20]$. Study also showed that VA has antioxidant properties and contains chemical composition such as flavonoids, saponins, terpenes, phenolic acids and others $[21,22]$. Reported that ethyl acetate fraction of Vernonia amygdalina has anxiolytic potentials in mice. However, there is little or no information on anxiolytic and explorative potential of Vernonia amygdalina in male wistar rats. Therefore, this study carried out anxiolytic and explorative properties of the methanol leaf extract of Vernonia amygdalina in male wistar rats.

\section{Materials and Methods}

Twenty five (25) male Wistar rats weighing between 80 -100g were used in this study. The Wistar rats were obtained from the animal house of the Bowen University, Iwo, Osun, Nigeria. The animals were housed and acclimatized in plastic cages with a wire screen top at the animal house of the Bowen University, Iwo, Osun state for two weeks before commencement of the neurobehavioral experiment.

\section{Plant preparation and extraction}

A bulk of fresh Vernonia amygdalina leaves sufficient for the study was collected from farm house in Bowen University, Iwo, Osun State Nigeria. It was then identified and authenticated in the botany 
department of the Bowen University, Iwo, Nigeria by Dr Ayanbamiji. The authentication number is BUH086.

The fresh leaves of Vernonia amygdalina were plucked from the stem and were air dried in the laboratory for about 61 days. The dried leaves were then reduced to powder using a grinder. The finely powdered leaves plant powder was then weighed and found to be $744 \mathrm{~g}$. Hence, $744 \mathrm{~g}$ of the plant was soaked in about $3090 \mathrm{mls}$ of $70 \%$ methanol and it was stirred. The mixture was then allowed to soak for about 72 hours; it was filtered first with a cheese cloth and then with Whitman filters paper in to a sterile container. The green colored filtrate was then evaporated to dryness in a rotary evaporator at $40^{\circ} \mathrm{C}$ so as to obtain the extracted leaf. The extract was then stored in a refrigerator for daily use. It was then dissolved in normal saline following standard of $1 \mathrm{~g} / 10 \mathrm{ml}$ for administration to the rats orally.

\section{Experimental animals and Treatment}

Male rats weighing $80-100 \mathrm{~g}$ were used in this study and were obtained from the Laboratory Animal Centre of the School of Health Science, Bowen University, Iwo, Osun, Nigeria. The animals were kept under favorable environmental condition, and fed with standard rodent pellet and water ad libitum. Animals were divided into four (4) groups: (1) saline, $10 \mathrm{ml} / \mathrm{kg}$ (2) methanol extract of Vernonia amygdalina (MEVA), 50mg/kg (3) MEVA, $100 \mathrm{mg} / \mathrm{kg}$, MEVA, $200 \mathrm{mg} / \mathrm{kg}$ and (4) standard drugs (Diazepam, $1 \mathrm{mg} / \mathrm{kg}$ ) before subjecting them to their respective models. The experimental procedures adopted in this study were in accordance with the United States National Institutes of Health Guidelines for Care and Use of Laboratory Animals in Biomedical Research (NIH, 1985).

\section{Phytochemical screening}

Methanol leaf extract of Vernonia amygdalina was screened for the presence or absence of various phytochemicals using standard procedures [23].

\section{Anxiety experimental models}

Open field test: The open-field area is made of acrylic transparent walls and black floor $(30 \mathrm{~cm}$ x $30 \mathrm{~cm}$ x $15 \mathrm{~cm})$ divided into nine squares of equal area. The open field is used to evaluate the exploratory activity of the animal [24]. The observed parameters are the number of squares crossed (with the four paws) and number of rearing, grooming. In Open field test, the number of line crosses and the frequency of rearing are usually used as a measure of locomotors activity and anxiety. A high frequency of this behavior indicates increased locomotion and exploration or a lower level of anxiety. Rearing frequency is the number of times the animal stood on its hind limbs or with its fore limbs resting on the wall of the observation cage or free in the air and grooming frequency is number of body cleaning with paws, picking of the body and pubis with mouth and face washing actions. After each test, the box is carefully cleaned up with $10 \%$ ethanol solution.

Hole- board apparatus: The apparatus is composed of a transparent Flexi glass area $(42 \times 42 \times 30 \mathrm{~cm})$ with 16 equidistant holes $2.5 \mathrm{~cm}$ in diameter in the floor [25]. The centre of each hole is 10 $\mathrm{cm}$ from the nearest wall of the box. The floor of the box is positioned $15 \mathrm{~cm}$ above the ground. An animal is placed in the center of the holeboard and allowed to freely explore the apparatus for 5 minutes, after the 5 minutes test, the animal was returned in its home cage and the

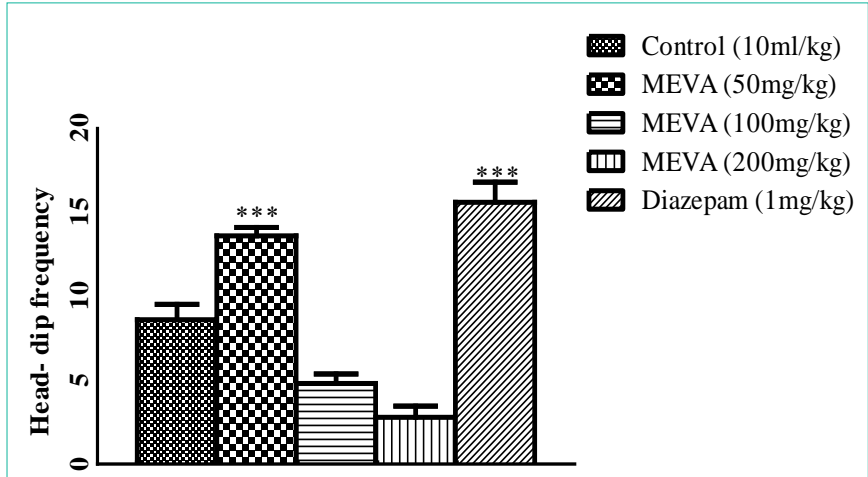

Figure 4: Effect of MEVA administration on Head-dip frequency in Holeboard test. The results are expressed as means \pm SEM $(n=6)$. Data were analyzed using One-way ANOVA followed by Newman-Keuls' post hoc test. ${ }^{* * *} p<0.01$ compared with the control.

Table 1: Phytochemical screening results.

\begin{tabular}{|c|c|}
\hline Plant constituents & Results \\
\hline Alkaloids & + \\
\hline Flavonoids & + \\
\hline Saponins & ++ \\
\hline Tanins & ++ \\
\hline Anthraquinones & + \\
\hline Terpenoids & + \\
\hline Cardiac glycosides & - \\
\hline
\end{tabular}

hole-board apparatus was cleaned with $10 \%$ ethanol and permitted to dry between tests and this prevent the incoming animal not to sense the odor of the previous animal.. The animal places its head into one of the holes, a minimum depth such that the ears were level with the floor of the apparatus. The number of head-dipping is recorded. A head dip is scored if both eyes disappear into the hole. The results are expressed as mean total number of head dips

\section{Statistical analysis}

The results obtained were expressed as mean \pm S.E.M. Variance was analyzed using One-way Analysis of Variance (ANOVA), followed by Newman- Keuls' multiple comparisons test. Statistical significance was set at $P<0.05$. All statistical analyses were done using (Graph-Pad Prism Software, San Diego, CA, USA) (Table 1).

\section{Results}

The results of the preliminary phytochemical screening revealed the presence of tannins, flavonoids, triterpenoids, saponins, terpenoids and anthraquinones (Figures 1-4).

Effect of methanol extract of Vernonia amygdalina in male rats on number of line crossed in Open Field Test.

Effect of methanol extract of Vernonia amygdalina in male rats on Rearing in Open Field Test.

Effect of methanol extract of Vernonia amygdalina in male rats on Grooming in Open Field Test.

Effect of methanol extract of Vernonia amygdalina on head-deep frequency in Hole-board Test. 


\section{Discussion}

Vernonia amygdalina (VA) methanol leaf extract showed significant anxiolytic, sedative and exploratory activity at a lower dose of $50 \mathrm{mg} / \mathrm{kg}$, VA showed a significant increase in the number of head dip responses, a significant increase in locomotion and rearing indicating its anxiolytic and exploratory activity at this least dose of the study $(50 \mathrm{mg} / \mathrm{kg})$.

V.amygdalina showed a dose dependent sedative activity at higher doses of $100 \mathrm{mg} / \mathrm{kg}$ and $200 \mathrm{mg} / \mathrm{kg}$ as indicated by significant reduction in rearing and locomotion in the open field test, reduction in number of head dip responses in the hole-board apparatus and a significant decrease in the Y-maze arm entries. At a dose of 200mg/ $\mathrm{kg}$, V.amygdalina also showed a significant increase in percentage alternation, an indication of higher spatial memory in the Y-maze apparatus.

The beneficial medicinal effects of plant materials typically result from the combinations of secondary metabolites present in the plant, through additive or synergistic action of several chemical compounds acting at single or multiple target sites associated with a physiological process [26]. Preliminary phytochemical screening in this study revealed the presence of alkaloids, tannins, terpenoids, flavonoids, anthraquinones and saponins. In the case of this study, the anxiolytic and sedative activities observed with V.amygdalina methanol leaf extract is possibly due to the presence of flavonoids, alkaloids, and terpenoids in the plant extract. These chemical constituents have been reported to be responsible for anxiolytic and sedative effects observed in different plant extracts [27].

In this study, V.amygdalina at the dose of $50 \mathrm{mg} / \mathrm{kg}$ increased the number of head-dips in a comparable manner to diazepam $1 \mathrm{mg} / \mathrm{kg}$ which is consistent with studies that have shown that benzodiazepine receptor agonists produce behavioural changes consistent with anxiety reduction while enhancing exploratory head-dipping [28], and this also corroborates the report of Casarrubea [29] who reported that the hole-board is an exploration-based assay widely used to asses features of anxiety-related behaviours in rodent and that an increase in head-dip frequency was suggestive of an anxiolytic activity. At doses of $100 \mathrm{mg} / \mathrm{kg}$ and $200 \mathrm{mg} / \mathrm{kg}$, the number of head dip responses was reduced in a significant manner. File and Wardill [30] reported that suppression of exploratory behavior is an indication of CNS depressant activity.

In this study at doses of $100 \mathrm{mg} / \mathrm{kg}$ and $200 \mathrm{mg} / \mathrm{kg}$, V.amygdalina produces a significant decrease in rearing and locomotion in the open field test indicating a central nervous system inhibitory activity which is consistent with the result from the hole-board test while at the dose of $50 \mathrm{mg} / \mathrm{kg}$ caused a significant increase in this behaviour. Rearing and locomotion are central excitatory locomotors behaviour associated with motivational state and arousal level and are regarded as 'arousal' or 'stress' phenomenon [31] and an increase or decrease in these index of alertness indicates an anxiolytic or sedative effect respectively [32].

In this study, all doses of V.amygdalina (50mg/kg-200mg/kg) did not have a significant effect on grooming compared to control, though it was decreased at a dose of $50 \mathrm{mg} / \mathrm{kg}$. However, diazepam produced a significant decrease in this activity. Grooming representing a typical displacement behavior is often seen in animal models of stress and anxiety, leading to a long standing view of grooming as a mere anxiogenic response.

The effects of $100 \mathrm{mg} / \mathrm{kg}$ and $200 \mathrm{mg} / \mathrm{kg}$ doses of V.amygdalina on the activity of the rats in the Y-maze arm entries showed that these doses are rather sedative and not anxiolytic consistent with previous information from the open field and hole-board test. The Y-maze can be used as a measure of short term memory, general locomotion activity and stereotypic behaviour [33]. Locomotors activity is an index that can be observed from the total number of arm entries [34]. In the present study, animals treated with different doses of V.amygdalina showed an improvement of the memory compared to control group. However, this improvement was significant only at the dose of $200 \mathrm{mg} / \mathrm{kg}$ and this may be due to the fact that it had a lower number of arm entries and thus an almost consistent percentage alternation. It is well known that spontaneous alternation is a measure of spatial working memory. Learning is a behavioral modification following an experience while memory involves the retention of the modification [35].

The effectiveness of V.amygdalina at $50 \mathrm{mg} / \mathrm{kg}$ in producing anxiolytic effects which suggests a possible positive modulation of both the $\mathrm{GABA}_{\mathrm{A}}$ - chloride channel receptors complex and 5-HT1A receptors complex. However, further studies will be needed using different receptors antagonists to ascertain whether or not the anxiolytic effect of VA at $50 \mathrm{mg} / \mathrm{kg}$ will be inhibited by these antagonists.

\section{Conclusion}

Results obtained in this study suggests that acute administration of the methanol leaf extract of V.amygdalina produced anxiolytic with a sedative effect which suggests a possible positive modulation of both the $\mathrm{GABA}_{\mathrm{A}}$ - chloride channel receptors complex and 5-HT1A receptors complex, increase in exploratory activity and slight improvement of short-term memory may suggest that V.amygdalina has some positive neuromodulatory potential to be explored.

\section{References}

1. Gorman JM. New molecular targets for anti-anxiety interventions. J Clin Psychiatry. 2003; 64: 28-35.

2. Olsen RW, Betz H. GABA and glycine In Siegel GJ, Albers RW, Brady S, Price DD (eds). Basic Neurochemistry: Molecular and Medical Aspects (7th ed.). Elsevier. 2006: 291-302.

3. Rudolph U, Möhler H. GABA-based therapeutic approaches: GABAA receptor subtype functions. Curr Opin Pharmacol. 2006; 6: 18-23.

4. Puri BK, Tyrer P. "Clinical psychopharmacolgy" Sciences Basic to Psychiatry (2nd ed.). Churchill Livingstone. 1998: 155-156.

5. Ijeh II, Ejike CECC. Current perspectives on the medicinal potential of Vernonia amygdalina Del. J Med Plant Res. 2011; 5: 1051-1061.

6. Kokwaro and John. Medicinal Plants of East Africa $3^{\text {rd }}$ ed. Nairobi, Kenya: University of Nairobi Press. 2009

7. Egedigwe CA. Effect of dietary incorporation of Vernonia amygdalina and Vernonia colorata on blood lipid profile and relative organ weights in albino rats (Thesis). Department of Biochemistry, MOUAU, Nigeria. 2010.

8. Muanya C. Bitter leaf-based extracts cures hepatitis co-inferation and others, the Guardian Newspaper. 2013.

9. Schiffers RR. African indigenous vegetables: an overview of the cultivated species. 2000. 
10. Ibrahim G, Abdurahman EM, Ibrahim H, Ibrahim NO. Comparative cytomorphological studies on the studies of V. amygdalina Del. and V. kotschyama. Nigerian Journal of Botany. 2010; 23: 133-142.

11. Abosi AO, Raseroka BH. In vivo antimalarial activity of Vernonia amygdalina. Br J Biomed Sci. 2003; 60: 89-91.

12. Amira OC, Okubadejo NU. Frequency of complementary and alternative medicine utilization in hypertensive patients attending an urban tertiary care centre in Nigeria. BMC Complement Altern Med. 2007; 7: 10.

13. Ajibola CF, Eleyinmi AF, Aluko RE. Kinetics of the inhibition of renin and angiotensin i converting enzyme by polar and non-polar polyphenolic extracts of Vernonia amygdalina and Gongronema latifolium leaves. Plant Foods Hum Nutr. 2011; 66: 320-327.

14. Gbolade AA. Inventory of antidiabetic plants in selected districts of Lagos State, Nigeria. J Ethnopharmacol. 2009; 121: 135-139.

15. Ogbera AO, Dada O, Adeyeye F, Jewo PI. Complementary and alternative medicine use in diabetes mellitus. West Afr J Med. 2010; 29: 158-162.

16. Koshimizu K, Ohigashi H, Huffman MA. Use of Vernonia amygdalina by wild chimpanzee: possible roles of its bitter and related constituents. Physiol Behav. 1994; 56: 1209-1216.

17. Nwanjo HU. Efficacy of aqueous leaf extract of vernonia amygdalina on plasma lipoprotein and oxidative status in diabetic rat models. Niger J Physiol Sci. 2005; 20: 39-42.

18. Adaramoye $\mathrm{O}$, Ogungbenro $\mathrm{B}$, Anyaegbu $\mathrm{O}$, Fafunso M. Protective effects of extracts of Vernonia amygdalina, Hibiscus sabdariffa and vitamin $C$ against radiation-induced liver damage in rats. J Radiat Res. 2008; 49: 123-131.

19. Babalola OO, Anetor JI, Adeniyi FA. Amelioration of carbon tetrachlorideinduced hepatotoxicity by terpenoid extract from leaves of Vernonia amydgalina. Afr J Med Med Sci. 2001; 30: 91-93.

20. Iwalokun BA, Efedede BU, Alabi-Sofunde JA, Oduala T, Magbagbeola OA, Akinwande Al. Hepatoprotective and antioxidant activities of Vernonia amygdalina on acetaminophen-induced hepatic damage in mice. J Med Food. 2006; 9: 524-530.

21. Erasto P, Grierson DS, Afolayan AJ. Bioactive sesquiterpene lactones from the leaves of Vernonia amygdalina. J Ethnopharmacol. 2006; 106: 117-120.

22. Onasanwo S.A., Aitokhuehi N.G., Ajayi O.P. and Faborode S.O. The Anxiolytic Properties of Vernonia amygdalina (Asteraceae) in Laboratory Mice. Afr J Biomed. Res. 2016; 19: 229-233.
23. Harborne JB. Phytochemical methods: a guide to modern techniques of plant analysis. London. Chapman and Hall. 1973: 49-188.

24. Archer J. Tests for emotionality in rats and mice: a review. Animal Behaviour 1973; 21: 205-235.

25. Moreira EG, Nascimento N, Rogero JR, Vassilieff VS. Gabaergicbenzodiazepine system is involved in the crotoxin-induced anxiogenic effect. Pharmacol Biochem Behav. 2000; 65: 7-13.

26. Briskin DP. Medicinal plants and phytomedicines - linking plant biochemistry and physiology to human health. Plant Physiology. 2000; 124: 507-514.

27. Houghton PJ. The scientific basis for the reputed activity of valerian. J Pharm Pharmacol. 1999; 51: 505-512.

28. Rodgers RJ, Cao BJ, Dalvi A, Holmes A. Animal models of anxiety: an ethological perspective. Brazilian Journal of Medical and Biological Research. 1997; 30: 289-304.

29. Casarrubea M, Filippina S, Santageb A, Crescimanno G. Microstructural Assessment of Rodent Behavior in the Hole-board. Proceedings of Measuring Behavior. 2010.

30. File SE, Wardill AG. Validity of head-dipping as a measure of exploration in a modified hole-board. Psychopharmacology. 1975; 44: 53-59.

31. Sadile AG. Long-time habituation of theta-related activity components of albino rats in the Lat-maze. In: Sanberg P.P, Ossenkopp K.P, Kavaliers M. (Eds). Motor activity and movement disorders: Measurement and analysis. 1995.

32. Thakur VD, Mengi SA. Neuropharmacology Profile of Eclipta alba (Linn.) Hassk. J Ethnopharmacol. 2005; 102: 23-31.

33. Kokkinidis L, Walsh MD, Lahue $\mathrm{R}$, Anisman $\mathrm{H}$. Tolerance to damphetamine: Behavioral specificity. Life Sci. 1976; 18: 913-917.

34. Lister RG. The use of a plus-maze to measure anxiety in the mouse Psychopharmacology. 1987; 92: 180-185.

35. Riedel G, Platt B, Micheau J. Glutamate receptor function in learning and memory. Behavioural Brain Res. 2003; 140: 1-47.
Ann Depress Anxiety - Volume 5 Issue 1 - 2018

ISSN : 2381-8883 | www.austinpublishing group.com

Lawrence et al. (C) All rights are reserved
Citation: Lawrence DA, Gbenro SA, Alaba OO, OLubayode B, Nimedia GA and Abiodun OA. Anxiolytic and Explorative Potentials of the Methanol Leaf Extract of Vernonia Amygdalina in Male Wistar Rats. Ann Depress Anxiety. 2018; 5(1): 1094 